\title{
Flow separation effects on shoreline sediment transport
}

Julia Hopkins, MIT-WHOI Joint Program in Civil and Environmental Engineering, Cambridge, MA

Steve Elgar and Britt Raubenheimer, Woods Hole Oceanographic Institution, Woods Hole, MA

Corresponding author: J. Hopkins, MIT/WHOI Joint Program, 15 Vassar Street Rm 48-208, Cambridge, MA, 02139 (hychenj@mit.edu)

\section{Key Words}

flow separation; inlet hydrodynamics; numerical modeling; coastal evolution; Delft3D

(C) 2016. This manuscript version is made available under the Elsevier user license http://www.elsevier.com/open-access/userlicense/1.0/ 


\begin{abstract}
Field-tested numerical model simulations are used to estimate the effects of an inlet, ebb shoal, wave height, wave direction, and shoreline geometry on the variability of bathymetric change on a curved coast with a migrating inlet and strong nearshore currents. The model uses bathymetry measured along the southern shoreline of Martha's Vineyard, MA, and was validated with waves and currents observed from the shoreline to 10-m water depth. Between 2007 and 2014, the inlet was open and the shoreline along the southeast corner of the island eroded $\sim 200 \mathrm{~m}$ and became sharper. Between 2014 and 2015, the corner accreted and became smoother as the inlet closed. Numerical simulations indicate that variability of sediment transport near the corner shoreline depends more strongly on its radius of curvature (a proxy for the separation of tidal flows from the coast) than on the presence of the inlet, the ebb shoal, or wave height and direction. As the radius of curvature decreases (as the corner sharpens), tidal asymmetry of nearshore currents is enhanced, leading to more sediment transport near the shoreline over several tidal cycles. The results suggest that feedbacks between shoreline geometry and innershelf flows can be important to coastal erosion and accretion in the vicinity of an inlet.
\end{abstract}




\section{Introduction}

2 Sediment transport on shorelines is affected by wave-orbital velocities, breaking-wave-driven

3 currents, tidal currents, and inlet flows. In particular, inlet flows can interrupt alongshore

4 sediment transport, resulting in sediment deposition inside the bay (flood tide delta), in the ocean

5 near the inlet mouth (ebb-tide delta or shoal) or farther offshore [1-4, references therein and

6 many others]. Erosion downstream of the inlet is possible owing to inlet-induced reduction in

7 alongshore sediment supply. The inlet influence can extend for more than $10 \mathrm{~km}$ along the coast

8 [5], although it often extends less than $4 \mathrm{~km}$ [4-7]. The inlet region of influence depends on

9 many factors, including the geometry of the ebb shoal and main inlet channel [8], the offshore

10 bathymetry $[9,10]$, wave climate $[11,12]$, tidal prism $[4,13]$, and the presence of headlands

$11[14,15]$.

12

13 Traditional knowledge associates increased sediment transport around the shoreline at Wasque

14 Point on the southeast corner of Martha's Vineyard, MA, USA (Figure 1) with the opening of the

15 nearby Katama Inlet [16]. Katama Inlet breached in 2007 near the middle of Norton Point

16 (Figure 1c) and migrated east until it closed in 2015 (Figure 1d). While the inlet was open, the

17 shoreline near the corner of Wasque Point eroded 200 m [Figure 1d, compare the purple curve

18 (2014) with the blue curve (2008, similar to 2007)]. Once Norton Point extended eastward and

19 wrapped around Wasque Point, closing the inlet, the corner reverted toward its 2007 position

20 [Figure 1d, compare the yellow curve (2015) with the blue curve (2008)]. Here it is shown that

21 although the erosion and subsequent accretion of the southeast corner of Martha's Vineyard is

22 consistent with a potential reduction (increase) in alongshore transport when the inlet is open

23 (closed), the variability of transport (magnitude of erosion plus magnitude of deposition) 
may impact the shoreline evolution.

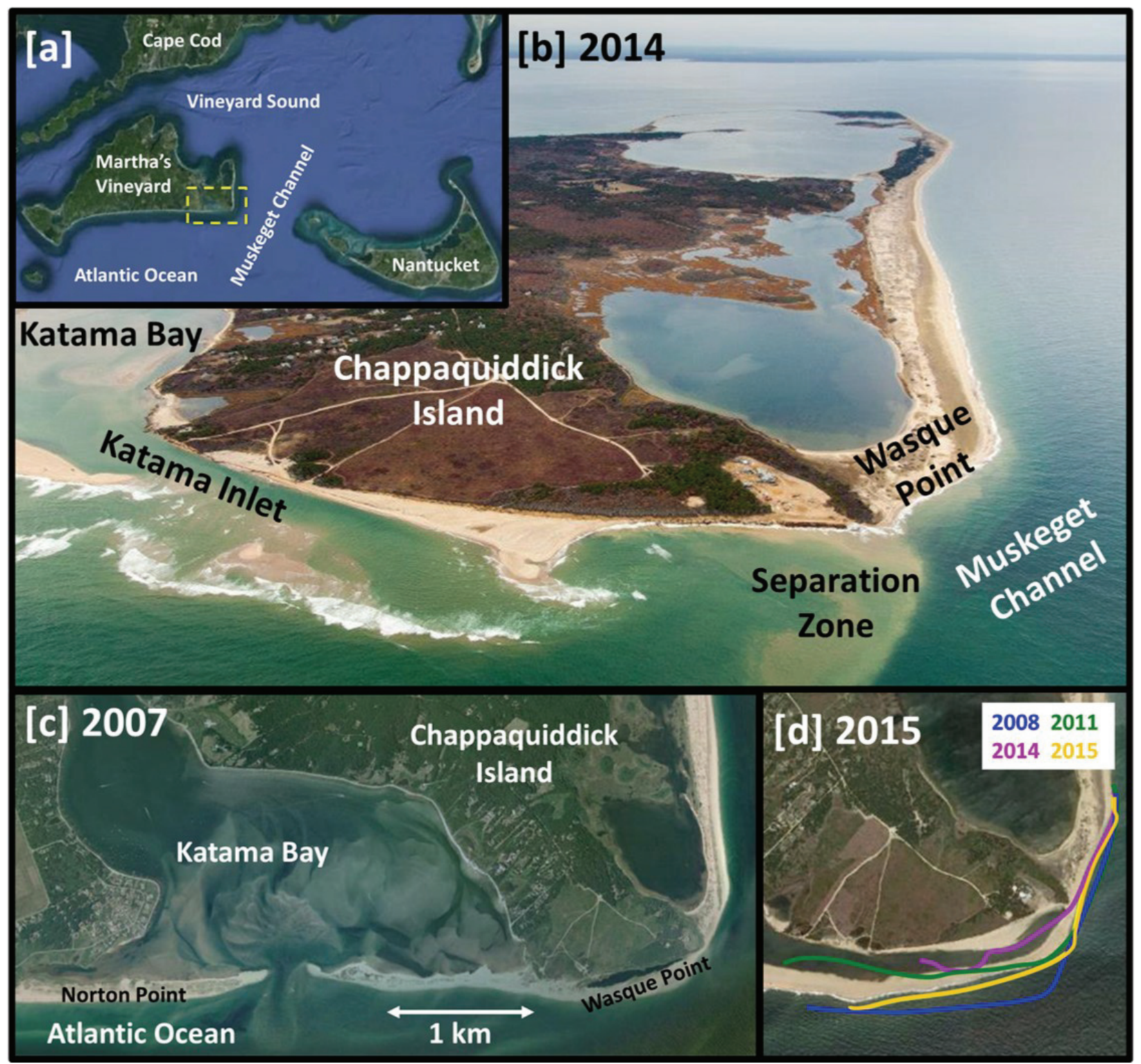

Figure 1: (a) Location of Martha's Vineyard, MA, (b) photograph of Chappaquiddick Island, Katama Bay and Inlet, and Wasque Point in 2014 [within the yellow box in (a)], (c) Google Earth image of the Katama area 2 months after Norton Point was breached in Apr 2007, and (d) close up image of Wasque Point in 2015, with shorelines from 2008 (blue curve, similar to 2007), 2011 (green), 2014 (purple), and 2015 (yellow). Photograph in (b) by Bill Brine.

Similar to the Martha's Vineyard coastline, many shorelines with inlets also have complex

34 larger-scale bathymetry and strong inner-shelf currents, including inlets throughout New

35 England [17], along the U.S. Atlantic Coast [18], and on sandy coasts around the world [12,19]. 
Strong currents near headlands or sharp shoreline transitions such as Wasque Point (Figure 1)

37 can impact sediment transport significantly. In particular, the separation of currents flowing

38 around headlands or sharp corners can generate eddies that suspend, transport, and deposit

39 sediment [18,20-23 and many others]. Flow separation and the generation of eddies depend on

40 the radius of curvature of the corner (or aspect ratio of a headland) [24], the balance of bottom

41 friction and current strength, and the ratio of flow strength to local acceleration [21]. Near

42 Wasque Point, the strong ebb jet through Muskeget Channel separates from the shoreline,

43 resulting in a quiescent zone at the southeastern corner of Chappaquiddick Island (Figure 1a,b).

44 The evolution of the radius of curvature of Wasque Point, a primary control of flow separation,

45 over the lifetime of Katama Inlet (Figure 1d) suggests that flow separation, in addition to the

46 inlet, could impact sediment transport at nearby shorelines. Here, field-tested numerical model

47 simulations are used to estimate the effects of an inlet, the ebb shoal, wave height, wave

48 direction, and shoreline geometry on erosion and deposition along a curved coast with a

49 migrating inlet.

50

51 2. Numerical simulations

52 Waves and currents were simulated with the numerical models SWAN (waves [25]) and

53 Delft3D-FLOW (currents [26]). The wave model solves the spectral action balance and includes

54 the effects of shoaling, refraction, and wave-current interaction. Similar to previous studies at

55 this location [27], for the no-wind cases and relatively short evolution distances here, wind and

56 nonlinear interactions were not included. The circulation model includes the effects of waves on

57 currents through wave radiation-stress gradients, combined wave and current bed shear stress, 
and Stokes drift. The wave and flow models were coupled such that FLOW passes water levels and Eulerian depth-averaged velocities to SWAN and SWAN passes wave parameters to FLOW.

61 SWAN was run with $3610^{\circ}$-wide directional bins and 37 frequency bands logarithmically

62 spaced between 0.03 and $1.00 \mathrm{~Hz}$. The model also used a depth-limited wave breaking

63 formulation without rollers [28], with the default value $\gamma=H_{\text {sig }} / h=0.73$ (where the significant

64 wave height $H_{\text {sig }}$ is 4 times the standard deviation of sea-surface elevation fluctuations, and $h$ is

65 the water depth), and a JONSWAP bottom friction coefficient associated with wave-orbital

66 motions set to $0.10 \mathrm{~m}^{2} / \mathrm{s}^{3}[27]$.

67

68 The circulation model was run using the 13 most energetic satellite-generated tidal constituents

69 [29] along open boundaries, which were dominated by the M2 ( $~ 80 \%$ of the variance, with small

70 variation along the boundary) and N2 ( $10 \%$ of the variance) constituents. In addition, the model

71 used a free slip condition at closed (land) side boundaries, a spatially uniform Chezy roughness

72 of $65 \mathrm{~m}^{0.5} / \mathrm{s}$ (roughly equivalent to a drag coefficient of $C_{d}=0.0023$ ) at bottom boundaries, and

73 default Delft3D parameters for coupling the FLOW and WAVE models [30]. Second-order

74 differences were used with a time step of $0.15 \mathrm{~s}$ for numerical stability.

75

76 Sediment transport [31] was simulated using the modeled waves and currents. Model parameters

77 were set to default values with a grain size of $300 \mu \mathrm{m}$, except for the reference height $(0.5 \mathrm{~m})$,

78 the current-related reference concentration factor (0.25), and the wave-related suspended and

79 bed-load transport factors (0.1), which were reduced from the default values (1) that smoothed

80 all bedforms and produced unrealistic transport around the island. Transport was averaged over 
81 several tidal cycles to remove variability within ebb or flood flows. The divergence

82 (convergence) of the transport vectors was used as a proxy for erosion (deposition), and the

83 morphology was not updated during the model run. These proxies primarily are a function of the

84 simulated hydrodynamics, which have been verified with field observations at this [27] and other

$85[10,32-35]$ shallow-water locations.

86

87 SWAN and Delft3D-FLOW (in depth-averaged mode) were run over 4 nested grids with both

88 two-way (FLOW) and one-way nesting (SWAN). The outermost grid, with $1 \mathrm{~km}$ resolution,

89 spans about $150 \mathrm{~km}$ along the north and south boundaries and $100 \mathrm{~km}$ along the east and west

90 boundaries. Nested in this coarse grid are finer grids of 200, 40, and $13 \mathrm{~m}$ resolution [27]. Using

91 higher resolution does not change simulation results significantly. Large-scale bathymetry within

92 the model domain was obtained during 1998 and 2008 USGS surveys (Northeast Atlantic 3 arc

93 second map [36] and Nantucket 1/3 arc second map [37]), and has horizontal resolution of 10 to

$9490 \mathrm{~m}$. The bathymetry near the shoreline, inlet channel, bay, and ebb shoal near Katama Inlet

95 was obtained each summer between 2011 and 2015 with a GPS and an acoustic altimeter

96 mounted on a jetski. The horizontal resolution of the jetski surveys is on the order of $10 \mathrm{~m}$, with

97 finer resolution near steep features. For 2008 (similar to 2007 immediately after the inlet was

98 breached), the location of the inlet and the geometry of the southeastern corner of

99 Chappaquiddick Island (Figure 1) were estimated from satellite images.

100

101 When initialized with frequency-directional spectra from WaveWatch III [38] along the offshore

102 boundary of the model domain, and run over the bathymetry observed in 2015 , the model

103 simulates the currents observed near the southeastern shoreline of Chappaquiddick Island, 
including the sharp gradient from the strong ebb flows in Muskeget Channel (red in Figure 2) to the quiescent zone of weak flows near the shoreline (blue in Figure 2). The observed currents were estimated with an acoustic Doppler current profiler (ADCP) mounted on a small boat. Each suite of six transects (Figure $2 \mathrm{a}$ and $2 \mathrm{~b}$ ) took about $2 \mathrm{~h}$, during which time the tidal flows of the discrepancies with the 1-h flow simulations.

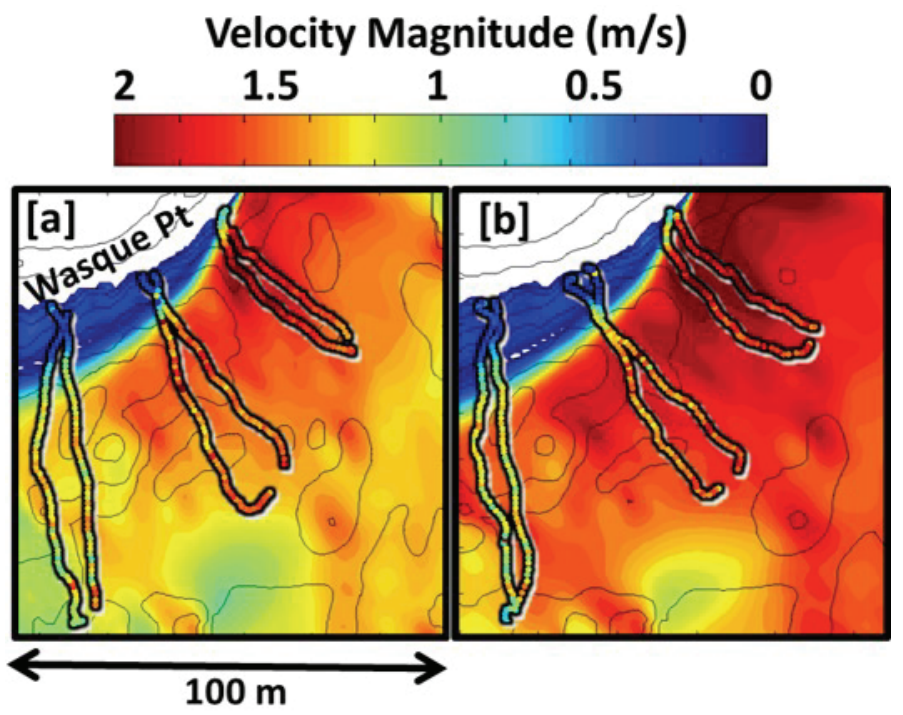

\section{Results and Discussion}

Model simulations were used to investigate the effects of the inlet, the ebb shoal, incident wave height, incident wave direction, and the shape of the southeast corner of Chappaquiddick Island (a proxy for flow separation) on erosion and deposition of sediment near Wasque Point. Along the offshore boundaries the model wave field had a JONSWAP spectral shape with $H_{\text {sig }}=1$ (representative of typical conditions in this area occurring $\sim 70 \%$ of the time in the last decade) or 
$1253 \mathrm{~m}$ (representative of storm events that occur $\sim 5 \%$ of the time) and $8 \mathrm{~s}$ waves with a $\cos ^{20}$

126 directional distribution centered either on shore-normal or $30^{\circ}$ west of normal. Tides on the

127 boundaries were set to values between spring and neap. Model simulations were averaged over

128 three tidal cycles for each year with observed nearshore bathymetry $(2008,2011-2015)$.

129

130 The radius of curvature of the southeast corner of Chappaquiddick Island is used as a proxy for 131 flow separation [24]. The center of the curve is at a point closest to where ebb flows begin to 132 separate from the shoreline, estimated as the location with the largest simulated cross-shore 133 velocity gradient near the corner (green circle in Figure 3a). The angles of tangents to the 134 shoreline (relative to the tangent at the center point) are calculated every $13 \mathrm{~m}$ on either side of 135 the center, and the slope of a least squares fit of distance as a function of angle is used as the 136 estimate of the radius of curvature (Figure $3 \mathrm{~b}$ ). The sum of the absolute values of total erosion 137 and total deposition within an area $+/-400 \mathrm{~m}$ from the center point extending from the shoreline 138 to 2-m water depth (Figure 3c) is used as a proxy for sediment transport. The results are not 139 significantly different for areas that extend between $+/-200$ to $+/-500 \mathrm{~m}$ tangential to the center 140 and to 4-m water depth. 

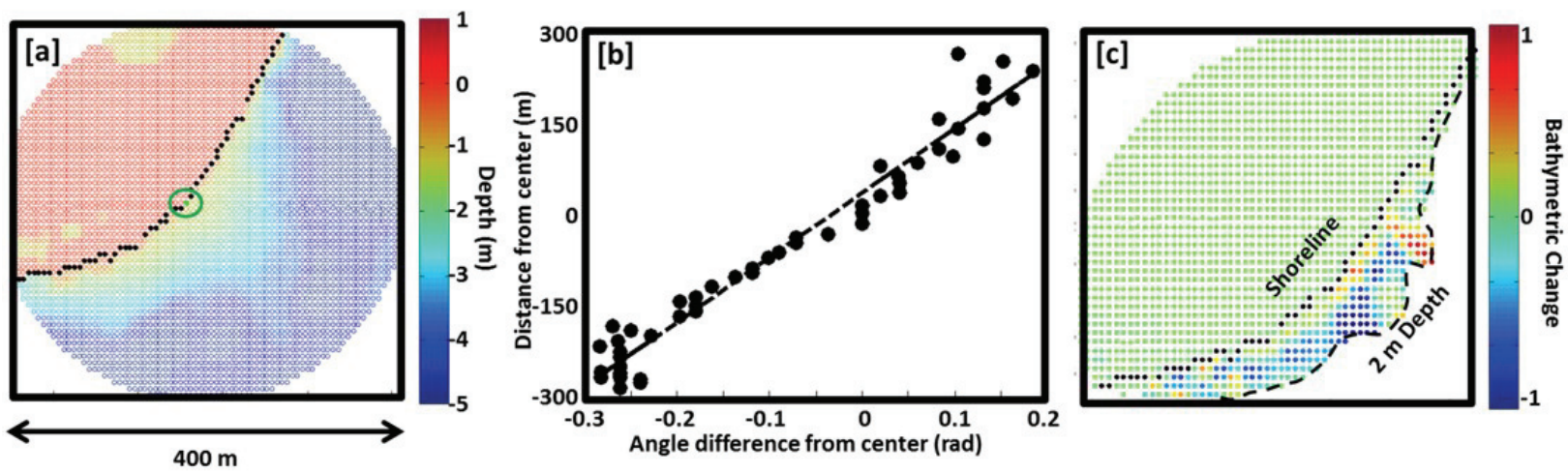

142

Figure 3: (a) Color contours of elevation (relative to mean sea level, scale on right) on the southeast corner of Chappaquiddick Island near Wasque Point in 2011. The black dots are the shoreline, and the green circle is the center of the radius of curvature. (b) Distance from the center point versus angle of tangents to the shoreline (relative to a tangent at the center). The slope of the least squares fit (dashed line) is the radius of curvature. (c) Color contours of erosion (blue) and deposition (red) (scale on right, arbitrary units) within a region between the shoreline (black dotted curve) and $2 \mathrm{~m}$ depth (black dashed curve).

Five scenarios were simulated for each of the 6 years with measured bathymetry. Erosion and

deposition were estimated for 1-m high normally incident waves using $i$ ) the measured

bathymetry (dark open circles in Figure 4), ii) the same bathymetry with the inlet artificially

closed (dark closed circles on Figure 4), and iii) with the inlet open, but the ebb-tidal delta (ebb

shoal) replaced with alongshore uniform bathymetry similar to that on either side of the shoal

(open squares in Figure 4). In addition, erosion and deposition were simulated for 3-m high

incident waves for each year using $i v$ ) the measured bathymetry with normally incident waves

(light open circles in Figure 4), v) the measured bathymetry with normally incident waves and

the inlet artificially closed (light closed circles, Figure 4), vi) the measured bathymetry with

waves from $30^{\circ}$ west of normal incidence (light open diamonds in Figure 4), and vii) the same

bathymetry with the inlet artificially closed with waves from $30^{\circ}$ west of normal incidence (light

closed diamonds in Figure 4). 


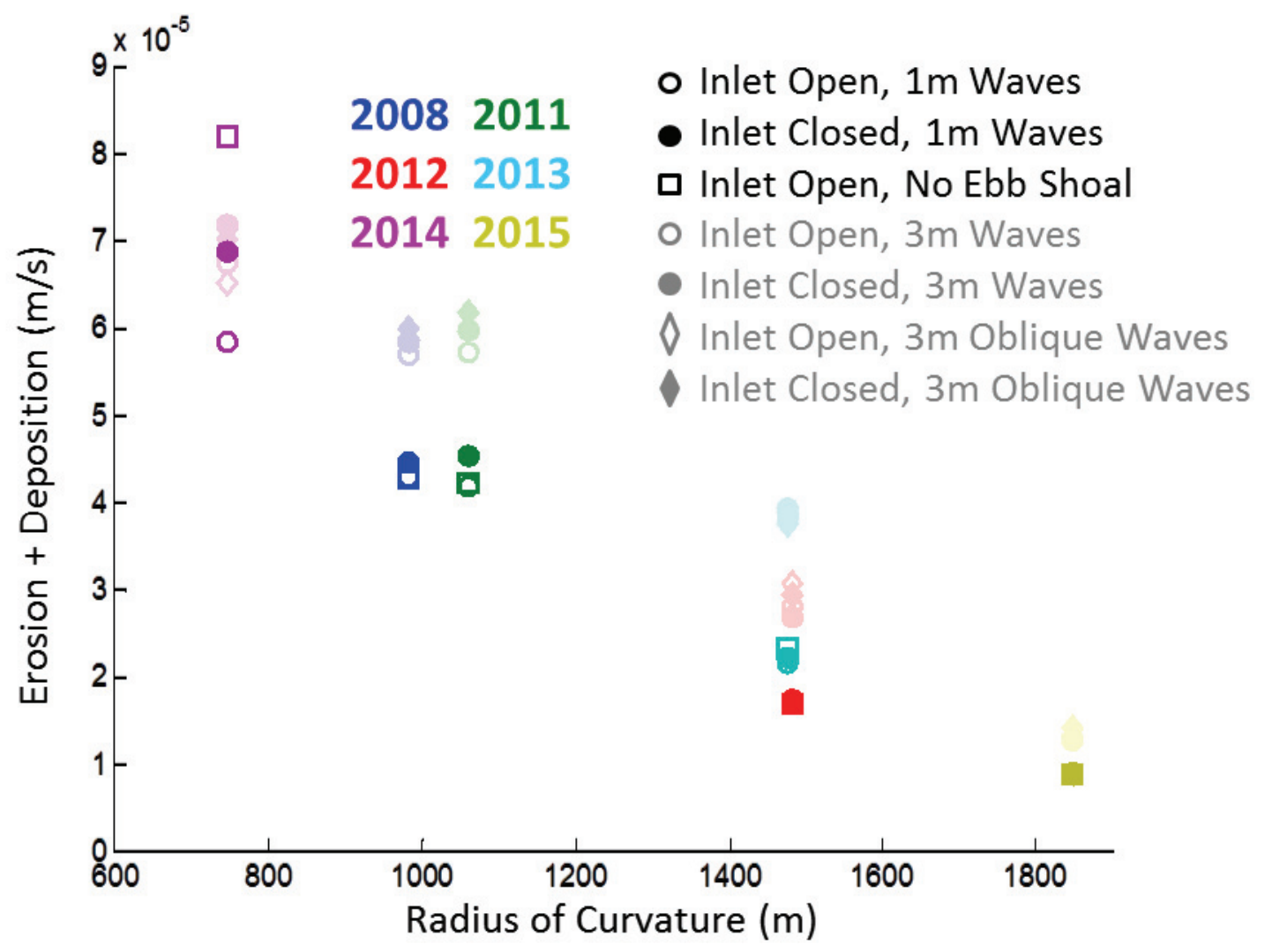

Figure 4. The sum of the absolute values of simulated erosion and deposition along $400 \mathrm{~m}$ of the shoreline between 0 - and 2-m water depths (Figure 3c) versus the radius of curvature of the southeastern corner of Chappaquiddick Island in each of 6 years (colors, legend in upper right). Simulations used the bathymetry observed each year with the inlet open (open symbols), with the inlet artificially closed (closed symbols), with normally (circles) and obliquely $\left(30^{\circ}\right.$ west of normal, diamonds) incident offshore wave directions, and with the ebb shoal removed artificially (open squares) for incident significant wave heights of 1 (dark colors) and $3 \mathrm{~m}$ (light colors). Inlet-open cases are not shown for 2015 because the inlet was closed.

Although momentum from the inlet flows during ebb tide tends to enlarge the separation region a few tens of meters (not shown), the simulated total erosion and deposition is not strongly affected by closing the inlet [compare open with closed circles for each year (colors) in Figure 4]. Similarly, removing the ebb shoal (Figure 4, open squares) does not have a significant effect on erosion and deposition, except in 2014 (Figure 4, purple symbols) when the inlet mouth and ebb shoal were $<0.5 \mathrm{~km}$ from Wasque Point (Figure 1b). Although as expected, there is more sediment motion with $3 \mathrm{~m}$ waves than with $1 \mathrm{~m}$ waves with the inlet open or closed (Figure 4, 
compare light with dark circles), and more transport with obliquely incident waves that drive

181 more alongshore flow (Figure 4, compare light diamonds with light circles), the differences in

182 erosion and deposition at the corner are relatively small. In contrast, the simulated erosion and

183 deposition depends more on changes in the radius of curvature than on the different scenarios in

184 any year (Figure 4), suggesting that sediment transport near the shoreline is influenced more by

185 separation from the coast of the strong Muskeget Channel ebb-tidal flows than on the presence or 186 absence of the inlet or the ebb shoal or on the details of the incident wave field.

188 The simulations further suggest that the geometry of the separation region and the intensity of 189 the separated jet combine to influence sediment transport at the southeast corner, and that the 190 vorticity generated at the boundary of the quiescent zone does not correlate to radii of curvature 191 or to erosion and deposition (not shown). Instead, tidally asymmetric transport is enhanced at the 192 shoreline when the corner is sharper (smaller radius) and the ebb-tide quiescent zone is larger, 193 because sediment is mobilized during the stronger flood flows and deposited during ebb when 194 currents decrease. The strength of the ebb jet outside of the quiescent zone also increases when 195 the corner is sharper, allowing for more sediment motion. In 2008, 1 year after Katama Inlet 196 formed, the radius of curvature was small and the simulations have relatively high erosion and 197 deposition near the shoreline (dark blue symbols in Figure 4). As the shoreline eroded between 1982011 and 2013, the radius of curvature increased, and although the shoreline continued to erode, 199 satellite images suggest the rate slowed (not shown), consistent with the reduction in simulated 200 erosion and deposition (2011 through 2013 in Figure 4). In 2014 the inlet mouth was south 201 (rather than west) of Chappaquiddick Island (compare Figure 1b with 1c), and Norton Point had 202 extended eastward to within the separation region (Figure 1b), resulting in a greatly sharpened 203 corner (Figure 1b, purple symbols in Figure 4), and increased erosion and deposition. Between 
204 summer 2014 (Figure 1b) and summer 2015 (Figure 1d) Norton Point extended rapidly (several

$205 \mathrm{~m} /$ day from satellite and visual observations) until the inlet closed. When the Norton Point sand

206 spit reached the shoreline near Wasque Point in 2015, the corner was smooth (largest radius of

207 curvature), and erosion and deposition was smallest (yellow symbols in Figure 4), consistent

208 with visual observations that suggest the shoreline did not evolve significantly between 2015 and

2092016.

210

211 Although the simulations suggest erosion and deposition near the shoreline do not depend

212 strongly on the presence or absence of the inlet, nor on wave-driven alongshore transport, there

213 is increased erosion downstream after the inlet opens, in contrast with a relatively stable

214 shoreline with the inlet closed (not shown). Disruption of alongshore transport or changes in

215 circulation when the inlet opens (e.g., the simulated tidally averaged momentum of the currents

216 near the southeast corner of Chappaquiddick Island decreases up to $10 \%$ when the inlet is open)

217 may enhance corner erosion and impact the strength of flow separation around the corner. Field-

218 verified simulations with evolving morphology might help determine why the shoreline starts to

219 erode when the inlet opens, and why the shoreline is stable when the inlet is closed. The

220 simulations here do not include morphological evolution. However, they suggest that erosion and

221 deposition decrease as the curvature of the southeast corner of Chappaquiddick Island increases

222 and separation from the coast of the strong Muskeget Channel ebb flows decreases. 


\section{Acknowledgements and data}

Data are available by e-mail to the authors. We thank Levi Gorrell and the PVLAB field crew for help obtaining the field observations, and Jeff Hansen for help with numerical modeling.

Funding was provided by NSF, Sea Grant (NOAA), NDSEG, ASD(R\&E), and ONR. 


\section{References}

[1] F.F. Escoffier, The stability of tidal inlets, Shore and Beach. 8 (1940) 114-115.

[2] P.D. Komar, D.L. Inman, Longshore sand transport on beaches, J. Geophys. Res. 75 (1970) 5914-5927.

[3] R. Slingerland, Systematic monthly morphologic variation of Assawoman Inlet: Nature and causes, Earth Surf. Process. Landforms. 8 (1983) 161-169. doi:10.1002/esp.3290080207.

[4] P.N. Adams, K.M. Keough, M. Olabarrieta, Beach morphodynamics influenced by an ebb-tidal delta on the North Florida Atlantic Coast, Earth Surf. Process. Landforms. (2015) n/a-n/a. doi:10.1002/esp.3877.

[5] M. Fenster, R. Dolan, Assessing the impact of tidal inlets on adjacent barrier island shorelines, J. Coast. Res. 12 (1996) 294-310.

[6] M.D. Hicks, T.M. Hume, A. Swales, M.O. Green, Magnitudes, spacial extent, time scales and causes of shoreline change adjacent to an ebb tidal delta, Katikati Inlet, New Zealand, J. Coast. Res. 15 (1999) 220-240.

[7] B. Castelle, P. Bonneton, H. Dupuis, N. Sénéchal, Double bar beach dynamics on the high-energy meso-macrotidal French Aquitanian Coast: A review, Mar. Geol. 245 (2007) 141-159. doi:10.1016/j.margeo.2007.06.001.

[8] D.M. Fitzgerald, Interactions between the ebb-tidal delta and landward shoreline: Price Inlet, South Carolina, J. Sediment. Petrol. 54 (1984) 1303-1318.

[9] F. Shi, D.M. Hanes, J.T. Kirby, L. Erikson, P. Barnard, J. Eshleman, Pressure-gradientdriven nearshore circulation on a beach influenced by a large inlet-tidal shoal system, J. 
Geophys. Res. 116 (2011) C04020. doi:10.1029/2010JC006788.

[10] J.E. Hansen, E. Elias, J.H. List, L.H. Erikson, P.L. Barnard, Tidally influenced alongshore circulation at an inlet-adjacent shoreline, Cont. Shelf Res. 56 (2013) 26-38. doi:10.1016/j.csr.2013.01.017.

[11] N. Robin, F. Levoy, O. Monfort, E. Anthony, Short-term to decadal-scale onshore bar migration and shoreline changes in the vicinity of a megatidal ebb delta, J. Geophys. Res. Earth Surf. 114 (2009) 1-13. doi:10.1029/2008JF001207.

[12] X. Bertin, A.B. Fortunato, A. Oliveira, A modeling-based analysis of processes driving wave-dominated inlets, Cont. Shelf Res. 29 (2009) 819-834. doi:10.1016/j.csr.2008.12.019.

[13] M.A. Powell, R.J. Thieke, A.J. Mehta, Morphodynamic relationships for ebb and flood delta volumes at Florida's tidal entrances, Ocean Dyn. 56 (2006) 295-307. doi:10.1007/s10236-006-0064-3.

[14] T.M. Hume, C.E. Herdendorf, Factors controlling tidal inlet characteristics on low drift coasts, 8 (1992) 355-375.

[15] M. O'Connor, J.A.G. Cooper, D.W.T. Jackson, Morphological behaviour of headlandembayment and inlet-associated beaches, Northwest Ireland, J. Coast. Res. SI 50 (2007) $626-630$.

[16] G. Ogden, Shoreline changes along the southeastern coast of Martha's Vineyard, Massachusetts for the past 200 years, Quat. Res. 4 (1974) 496-508.

[17] D.M. Fitzgerald, I. V Buynevich, R.A. Davis Jr, M.S. Fenster, New England tidal inlets with special reference to riverine-associated inlet systems, Geomorphology. 48 (2002) $179-208$. 
[18] J.E. Mcninch, R.A. Luettich, Physical processes around a cuspate foreland: implications to the evolution and long-term maintenance of a cape-associated shoal, Cont. Shelf Res. 20 (2000) 2367-2389.

[19] E. Chaumillon, F. Ozenne, X. Bertin, N. Long, F. Ganthy, Wave climate and inlet channel meander bend control spit breaching and migration of a new inlet: La Coubre Sandspit, France., J. Coast. Res. (2014). doi:10.2112/SI65-xxx.1.

[20] J.L. Best, Flow dynamics at river channel confluences: Implications for sediment transport and bed morphology, Recent Dev. Fluv. Sedimentol. Spec. Publ. SEPM Soc. Sediment. Geol. (1987) 27-35. doi:10.2110/pec.87.39.0027.

[21] R.P. Signell, W.R. Geyer, Transient eddy formation around headlands, J. Geophys. Res. 96 (1991) 2561-2575.

[22] L. White, E. Wolanski, Flow separation and vertical motions in a tidal flow interacting with a shallow-water island, Estuar. Coast. Shelf Sci. 77 (2008) 457-466. doi:10.1016/j.ecss.2007.10.003.

[23] K.C. Spiers, T.R. Healy, C. Winter, Ebb-jet dynamics and transient eddy formation at Tauranga Harbour: Implications for entrance channel shoaling, J. Coast. Res. 25 (2009) 234-247. doi:10.2112/07-0947.1.

[24] J.L. Best, I. Reid, Separation zone at open-channel junctions, J. Hydraul. Eng. 110 (1984) 1588-1594. doi:10.1061/(ASCE)0733-9429(1984)110:11(1588).

[25] N. Booij, R.C. Ris, L.H. Holthuijsen, A third-generation wave model for coastal regions: 1. Model description and validation, J. Geophys. Res. 104 (1999) 7649. doi:10.1029/98JC02622.

[26] G.R. Lesser, J.A. Roelvink, J.A.T.M. van Kester, G.S. Stelling, Development and 
validation of a three-dimensional morphological model, Coast. Eng. 51 (2004) 883-915. doi:10.1016/j.coastaleng.2004.07.014.

[27] J.A. Hopkins, S. Elgar, B. Raubenheimer, Observations and model simulations of wavecurrent interaction on the inner shelf, J. Geophys. Res. Ocean. 120 (2015) 1-11. doi:10.1002/2015JC010788.

[28] J.A. Battjes, J.P.F.M. Janssen, Energy loss and set-up due to breaking of random waves, in: Int. Conf. Coast. Eng., 1978: pp. 569-587.

[29] G.D. Egbert, S.Y. Erofeeva, Efficient inverse modeling of barotropic ocean tides, J. Atmos. Ocean. Technol. 19 (2002) 183-204.

[30] Deltares, Delft3D-Wave. Simulation of short crested waves with SWAN. User manual. Deltares, Rotterdamseweg 185, The Netherlands. (2014)

[31] L. Van Rijn, Principles of Sediment Transport in Rivers, Estuaries and Coastal Seas, Aqua Publishing, Blokzijl, Netherlands, 1993.

[32] R.P. Mulligan, A.E. Hay, A.J. Bowen, A wave-driven jet over a rocky shoal, J. Geophys. Res. 115 (2010) C10038. doi:10.1029/2009JC006027.

[33] E.P.L. Elias, G. Gelfenbaum, A.J. Van der Westhuysen, Validation of a coupled waveflow model in a high-energy setting: The mouth of the Columbia River, J. Geophys. Res. Ocean. 117 (2012). doi:10.1029/2012JC008105.

[34] J.E. Hansen, T.T. Janssen, B. Raubenheimer, F. Shi, P.L. Barnard, I.S. Jones, Observations of surfzone alongshore pressure gradients onshore of an ebb-tidal delta, Coast. Eng. 91 (2014) 251-260. doi:10.1016/j.coastaleng.2014.05.010.

[35] J.E. Hansen, B. Raubenheimer, J.H. List, S. Elgar, Modeled alongshore circulation and force balances onshore of a submarine canyon, J. Geophys. Res. Ocean. 120 (2015) 1887- 
1903. doi:10.1002/2014JC010555.

[36] National Geophysical Data Center, U.S. Coastal Relief Model - Northeast Atlantic, Natl. Oceanic and Atmos. Admin., Boulder, Colo. (1999) doi:10.7289/V5MS3QNZ

[37] B.W. Eakins, L.A. Taylor, K.S. Carignan, R.R. Warnken, E. Lim, P.R. Medley, Digital elevation model of Nantucket, Massachusetts: Procedures, data sources and analysis, NOAA Technical Memorandum NESDIS NGDC-26, Dept. of Commerce, Boulder, CO, (2009) 29

[38] H.L. Tolman, User manual and system documentation of WAVEWATCH-III version 2.22, NOAA / NWS / NCEP / MMAB Tech. Note. 222 (2002) 133. 